Journal of Applied Biology \& Biotechnology Vol. 5 (02), pp. 085-088, March-April, 2017

Available online at http://www.jabonline.in

DOI: 10.7324/JABB.2017.50213

(c)) EY-NC-SA

\title{
In-Vitro Propagation of Dioscorea alata for Tyrosinase Production
}

\author{
B. Gopal Samy ${ }^{1 *}$, K. Jegatheesan ${ }^{2}$, C. Infant Francina ${ }^{3}$ \\ ${ }^{1}$ Department of Biotechnology, Liatris Biosciences LLP Kottayam, Kerala, India. \\ ${ }^{2}$ Center for Research and PG Studies in Botany and Department of Biotechnology Thiagarajar College (Autonomous) Madurai - 625009 , India. \\ ${ }^{3}$ Department of Biotechnology St. Michael College of Engineering \& Technology Kalayarkoil - 630 551, Tamil Nadu, India.
}

\section{ARTICLE INFO}

\section{Article history:}

Received on: 27/11/2016

Accepted on: 29/12/2016

Available online: 20/03/2017

Key words:

Yam, callus, picloram,

2,4-D, L-DOPA.

\begin{abstract}
The copper-containing metalloprotein tyrosinase catalyzes the oxidation of tyrosine in particular L-DOPA to L-Dopaquinone that generates brown pigments in the wounded tissues. The industrial demand for tyrosinase enzyme is increasing as they have a wide range of applications in the field of environmental, food, medicine, paper, pulp and textile industry. In the present investigation, tyrosinase was extracted from various plant sources and Dioscorea alata having a maximum enzyme activity was chosen. The different parts of plant material were taken for callus development and their enzyme activities were estimated. The enzyme activities of all calli were high comparing to the enzyme extracted from natural tuber tissue of D. alata making in-vitro culture as an alternative way for tyrosinase production. It is also evident that 2,4-D has the maximum callus development comparing to other plant growth regulators making it a perfect candidate for proceeding further with media optimization in future.
\end{abstract}

\section{INTRODUCTION}

Tyrosinase (E.C: 1:14:18:1) is an enzyme that produces a black pigment by oxidizing tyrosine by means of atmospheric oxygen. Assorted phenols to colored compounds were oxidized by tyrosinase and oxidation products were formed with dihydroxy phenylalanine and pyrogallol. A black pigment called melanin was formed from this dihydroxy phenylalanine, analogous to that formed from tyrosine. The group of catechol oxidase (E.C: 1:10:3:1), laccase (E.C: 1:10:3:2) and tyrosinase were called Poly Phenol Oxidase. This tyrosinase enzyme has a wide range of industrial applications like production of L-DOPA in the field of medicine; detection, quantification and removal of phenolic compounds from water and bioremediation in the field of environmental pollution and production of cross linked polymers in food industry. Because of such an enormous need for the enzyme, development of novel enzyme production methods is needed. Yams are also one of the richest sources of this enzyme and it has been grown in India since very ancient times.

* Corresponding Author

B Gopal Samy, Sr. Scientist \& CSO, Department of Biotechnology, Liatris Biosciences LLP, Sarangi Towers, Thalayolaparambu, Kottayam E-mail: gopalsamy2k6@gmail.com
Dioscorea alata commonly called as yam, originated from India was a fundamental food and commercial crop all over the world because of its wealthy carbohydrate and vitamin resource with high calorific value [1]. The genus Dioscorea has 600 species with significant economic importance [2] among which 14 are used as edible tubers. India hold a rich genetic diversity of tuber crop especially yam Dioscorea [3]. Dioscorea alata $L$. is a significant tuber crop forming a basic food for majority of peoples in subtropical and tropical countries [4]. Dioscorea alata is a main crop in West Africa, Caribbean Central and South America [5]. Pulverized tubers were used as a remedy for gonorrhea, piles and applied externally to sores.

Tubers boast a dual function as they provide nourishment as a food source and also operate as a planting material [6] for vegetative propagation. But numerous virus and fungal diseases impede the tuber production [7]. Standard yam propagation by seeds was sluggish and insufficient for quick reproduction. Nematode and viral infections not only trim down tuber yield radically but also spread to the subsequent generation [8] worsening the tuber quality [9].

Many reasons like deficiency of agronomic constraints and good healthy planting materials along with phytosanitary troubles restrict tuber production. In vitro propagation might help to overcome constraints related with availability of high quality of planting material [10] and paved a way to boost the rapid virus free plant material production. 
Tissue culture was an impending way of fabricating handy plant products avoiding all the drawbacks and hindrances in usual agriculture like crop adulteration, disease, environmental factors, handling and storage losses, quality variation, political and labor instabilities in the producing countries. It was an attractive proposal to manufacture important secondary metabolites in bulky bioreactors placed in the using country itself [11].

Callus formation from explants entailed the progressive, more random plane cell division development, prearranged structure loss and less frequent cell specialization [12, 13]. Callus growth can be monitored by fresh weight measurements that are convenient for observing the growth of cultures over time in a non-destructive manner.

In this study, we focused on selecting a plant source for tyrosinase based on its enzyme activity. The chosen plant material was then used for callus development and the enzyme was again extracted from the callus. The enzyme activity from Dioscorea alata tubers as well as the callus developed from various parts of D. alata was compared to determine the best source for enzyme production.

\section{MATERIAL \& METHODS}

\subsection{Plant samples \& Chemical requirements}

The plant samples like yam, elephant yam and potato were obtained from the agriculture fields close to Sivagangai. Mushroom was obtained from Nila fruits and vegetables, Madurai. Analytical Grade Tyrosine, different $\mathrm{pH}$ buffers, distilled water, Sodium Phosphate buffer ( $\mathrm{pH}-7.0)$ and other general reagents and chemicals used for the present study were purchased from SDFine chemicals.

\subsection{Tyrosinase Extraction}

The tubers of yam, elephant yam and potato were washed with distilled water, skin peeled off and the inner tissue was sliced. Similarly mushroom was sliced into pieces and these sliced plant material were used as enzyme source. About 5 grams of each plant tissue was homogenized with $20 \mathrm{ml}$ of $0.2 \mathrm{M}$ sodium phosphate buffer in separate mortar and pestle. After centrifugation at $5000 \mathrm{rpm}$ for 15 minutes, the supernatant was separated and precipitated with acetone. This precipitate was lyophilized and resolubilized with buffer for further use.

\subsection{Tyrosinase Assay}

In a clean test tube, $0.5 \mathrm{ml}$ of enzyme extract and $3 \mathrm{ml}$ of $0.1 \mathrm{M}$ Sodium phosphate buffer was pipetted and $1 \mathrm{ml}$ of $1 \%$ tyrosine solution was added to it. The enzyme-substrate mixture was immediately transferred into a quartz cuvette and placed in the spectrophotometer. Absorbance values were read at $475 \mathrm{~nm}$ for every 30 seconds up to 300 seconds. The absorbance values were recorded and using this absorbance value, the concentration of dopachrome was calculated by Beer-Lambert's law and from that the enzyme activity is expressed in katal (kat).

\subsection{Establishment of Aseptic Cultures}

Explants collected from field-grown D. alata plants are usually contaminated by various microorganisms. The surface contaminants were excluded by washing in the appropriate common sterilizing agents like sodium hypochlorite (1-5\%), ethyl alcohol (70-90\%) and mercuric chloride $(0.1-1 \%)$ for $10-30 \mathrm{~min}$ followed by several rinses in sterile water. $0.3 \%$ Bavistin, $1 \%$ benomyl, $0.3-0.5 \%$ streptomycin and detergent are also used as surface sterilizing agent.

\subsection{Culture Media}

A nutrient medium should contain all the necessary major and minor plant nutrient elements, plant growth regulators, vitamins, carbon source and other organic substances as optimal additives. For preparing solid and semi-solid culture media, agar powder is most commonly used. The MS basal medium formulation described by [14] containing $30 \mathrm{gl}^{-1}$ sugar, $0.1 \mathrm{gl}^{-1} \alpha$ cysteine, $10 \mathrm{mgl}^{-1}$ calcium pantothenic acid, $2 \mathrm{mgl}^{-1}$ asparagine, 2 $\mathrm{mgl}^{-1}$ arginine and $6 \mathrm{gl}^{-1}$ agar was used throughout this study for in vitro propagation of Dioscorea alata $[15,16,17]$. The medium $\mathrm{pH}$ was adjusted to 5.8 prior to autoclaving at $121^{\circ} \mathrm{C}$ for 20 minutes.

\subsection{Growth Substances}

The quantity and type of plant growth regulators incorporated in the culture medium determines the success of tissue culture work. Induction and differentiation of callus and formation of root and shoot were closely synchronized by the relative auxin and cytokinin concentration in the medium [18]. The gibberellins that stimulate callus formation were used as plant growth regulators (PGR) in this study.

\subsection{Incubation Condition}

The two imperative factors in culture incubation were light and temperature. Cool, white fluorescent lamps providing under 30-50 $\mu_{\text {molm }} \mathrm{s}^{-1}$ of light exposure for 12-16 $\mathrm{h}$ per day was usually used. The temperature of the culture incubation room was maintained at around $25^{\circ} \mathrm{C}$. Due to high phenolic content in yam tissue, mostly it was incubated in darkness to avoid browning.

\subsection{Preparation of Explants}

Dioscorea alata plants (2 month old) were collected from nearby fields in Sivagangai district and were utilized as explants for plant tissue culture. Explants were thoroughly washed with tap water and then soaked in $0.1 \%(\mathrm{v} / \mathrm{v})$ of fungicide solution for 10 min followed by sterile distilled water rinsing for four times. Then they were surface sterilized in a viable chlorine bleach containing $4.5 \%$ chlorine for 20 minutes and rinsed in a sterile distilled water for four times. Then they were cut into single pieces of specific dimensions.

\subsection{Callus Induction from Vegetative Tissues}

Stem (5 mm long), leaf $(5 \mathrm{~mm} \times 5 \mathrm{~mm})$, corm tuber $(5$ $\mathrm{mm} \times 5 \mathrm{~mm}$ ) and petiole ( $5 \mathrm{~mm}$ long) pieces obtained from two month old plantlets from the cultivation fields were evaluated for 
callus formation. The treatment media were prepared by dissolving $1 \mathrm{mgl}^{-1}$ of picloram, 2,4-D and NAA separately in MS media. The control tube was prepared by having MS media alone without PGR. The explants were inoculated in glass tube containing $15 \mathrm{ml}$ of treatment medium and incubated in dark at $25^{\circ} \mathrm{C}$ for 10 days. The most suitable type of explants and PGR was determined based on the highest percentage of callus formation.

\subsection{Tyrosinase Extraction from Callus}

The callus obtained from all the four types of explants namely nodal stem, leaf, corm tuber and petiole of $D$. alata were sliced aseptically and $10 \mathrm{~g}$ of each callus was weighed accurately and minced with a razor blade on a piece of aluminum foil. The Minced callus tissues were transferred to a mortar and $10 \mathrm{ml}$ of 0.2 $\mathrm{M}$ phosphate buffer of $\mathrm{pH} 7$ was added and ground to a fine slurry using a pestle. The slurry is then poured onto a small funnel lined with 4 layers of cheesecloth or muslin cloth and strained into a 15 $\mathrm{ml}$ screw-top centrifuge tube. The collected filtrate is then balanced and Centrifuged for $15 \mathrm{~min}$. at $3500 \mathrm{rpm}$. After centrifugation, the supernatant was poured into a fresh $15 \mathrm{ml}$ centrifuge tube, labeled and stored in a fresh bottle in refrigerator for further assay.

\section{RESULTS \& DISCUSSION}

\subsection{Selection of Plant Source}

The enzyme activity of the crude enzyme extracted from the different plant sources were estimated by continuous spectrophotometric rate determination. The results showed that crude enzyme extracted from Dioscorea alata has the maximum enzyme activity of $10588.2 \mu \mathrm{katml}^{-1}$ followed by mushroom with next highest enzyme activity (Figure 1).

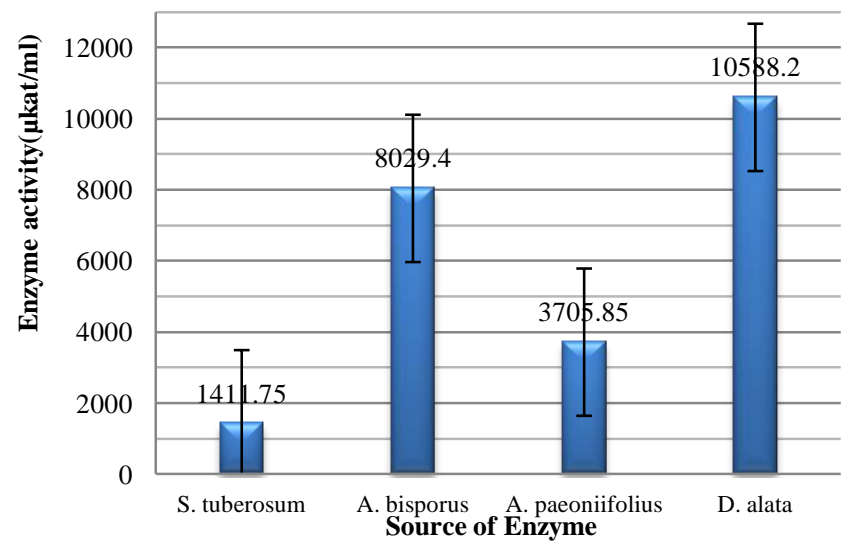

Fig. 1: Comparison of tyrosinase activity from various sources.

\subsection{Callus Formation}

2,4-D, NAA and picloram at $1 \mathrm{mgl}^{-1}$ induced callus formation from leaf, petiole, corm tuber and nodal stem tissues of D. alata after six weeks of culture in the dark. However, these explants did not form callus in the medium without PGR (control). The medium added with $1 \mathrm{mgl}^{-1} 2,4-\mathrm{D}$ or picloram induced higher percentage of explants that produced callus compared to $1 \mathrm{mgl}^{-1}$
NAA. Callus started forming around the edges of the cut area of explant tissue (Fig. 2). Among the four types of explants, the nodal stem produced the highest percentage of purplish nodular embryogenic callus (Fig. 3). Similar results from nodal cuttings were already obtained [19].

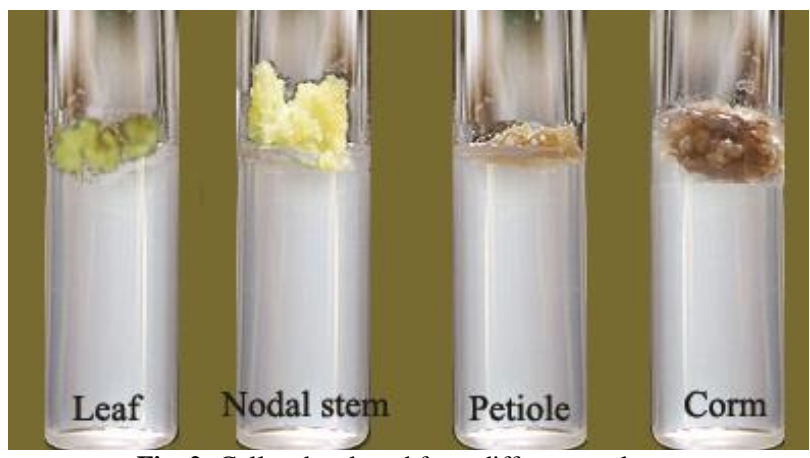

Fig. 2: Callus developed from different explants

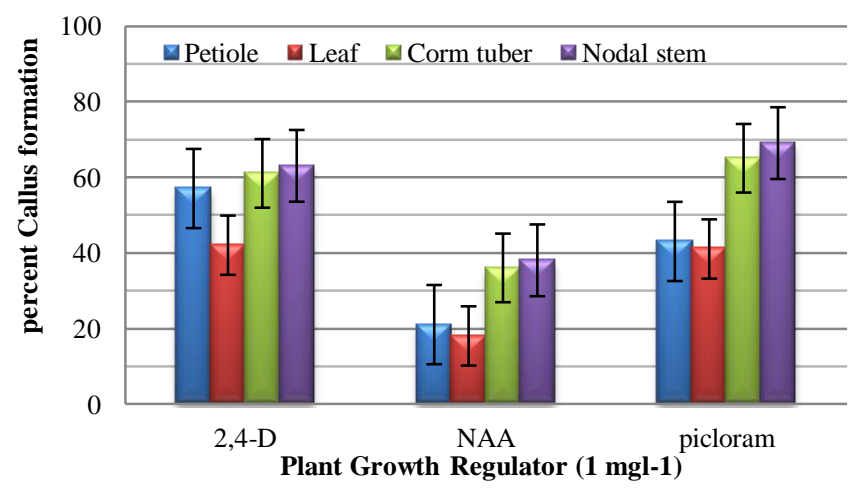

Fig. 3: Percent Callus formation from various explants \& PGR

In contrast, the other three explants produced soft fine non-embryogenic callus that were highly vacuolated. More than $50 \%$ of the leaf and petiole explants became totally brown and necrotic due to phenolic substances that were exuded from the cut portion [20]. Tissue browning inhibits the production of callus and in severe cases led to the death of tissue [21]. The callus developed from $1 \mathrm{mgl}^{-1} 2$, 4-D was used for enzyme extraction and assay as they show relatively good percent of callus formation for all explants.

\subsection{Tyrosinase Extraction and Assay}

The crude enzyme was isolated from the callus tissues and their enzyme activity was estimated by continuous spectrophotometric rate determination. The results showed that crude enzyme extracted from callus developed from corm tuber has the maximum enzyme activity (Fig. 4) even though nodal stem has the highest percentage of callus. Comparatively the enzyme activity from all the callus was much higher than the enzyme isolated from naturally grown tuber tissue of $D$. alata. This clearly depicts that in vitro culture can be done for increasing the production of enzyme activity. Also in future the in vitro culture 
media composition can be optimized using response surface methodology to get more yield of tyrosinase from the callus.

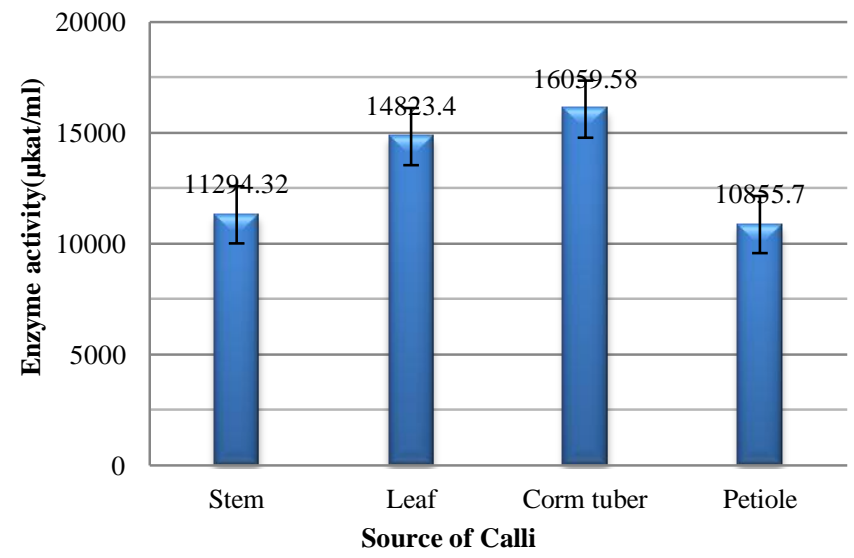

Fig. 4: Comparison of tyrosinase activity from various callus

\section{CONCLUSION}

Among the four different explants, nodal stem show higher percentage of callus formation whereas the enzymatic activity was higher in callus from corm tuber. Because of the high phenolic content, the calli were brown in color. The enzyme activities of all calli were high comparing to the enzyme extracted from natural tuber tissue of $D$. alata making in-vitro culture as an alternative way for the production of tyrosinase. It was also evident that $1 \mathrm{mgl}^{-1}$ 2,4-D has the maximum calli development comparing to other plant growth regulators making it a perfect candidate for proceeding further with media optimization in future.

\section{Financial support and sponsorship: Nil.}

Conflict of Interests: There are no conflicts of interest.

\section{REFERENCE}

1. Pandey SK. Potato and tuber crops. In:Vegetable science (Vegetable tuber and spice crops) Shimla: Central Potato Research Institute; 2007.

2. Ayensu ES. Anatomy of the monocotyledons VI Dioscoreales. Oxford: Oxford Press; 1972, p. 182

3. Hann SK. Yams. Dioscorea spp. (Dioscoreaceae). In: Smartt J, Simmonds NW, editors. Evolution of crop plants, UK Longman Scientific and Technical; 1995, p. 112.

4. Edison S, Unnikrishnan M, Vimala B, Santha Pillai V, Sheela MN, Sreekumari MT, Abraham K. Biodiversity of Tropical Tuber Crops in India. NBA Scientific Bulletin. 2006; 7:60.

5. Tor M, Twyford CT, Funes I, Boccon-Gibod J, Ainsworth CC, Mantell SH. Isolation and culture of protoplasts from immature leaves and cell suspension of Dioscorea yams: Tools for transient gene expression studies. Plant Cell, Tissue and Organ Culture. 1998; 53:113-125.

6. Craufurd PQ, Battey NH, Ile EI, Asedu R. Phases of dormancy in yam tubers (Dioscorea rotundata). Annals of Botany. 2006; 97:497504.
7. Saleil V, Degras L, Jonard R. Obtention de plantes indemmes de virus de la mosaique de l'igname americaine Dioscorea trifida $L$. Agronomie. 1990; 10:605-615.

8. Ng SYC. Micropropagation of white yam (Dioscorea rotundata Poir) In: Bajaj YPS, editor. Biotechnology in agriculture forestry, Berlin: Springer; 1992, p. 135-159.

9. Mitchell SA, Ahmed MH. Morphological changes of Dioscorea trifida L.cv. Short Neck Yampie and Dioscorea cayenensis Lam cv. round leaf yellow yam linked to the number and size of harvested tubers. The Journal of Horticultural Science and Biotechnology. 1999; 74:531-539.

10. Vaillant V, Bade P, Constant C. Photoperiod affects the growth and development of yam plantlets obtained by in vitro propagation. Biologia Plantarum. 2005; 49:355-359.

11. Barz W, Ellis BE. Plant cell cultures and their biotechnological potential. Berichte der Deutschen Botanischen Gesellschaft. 1981; 94:1-26.

12. Thorpe TA. Organogenesis in vitro: structural, physiological and biochemical aspects. International Review of Cytology. 1980; 11:71112

13. Wagley LM, Gladfelter HJ, Phillips GC. De novo shoot organogenesis of Pinus eldarica Medw. In vitro. II. Macro-and micro-photographic evidence of de novo regeneration. Plant Cell Reports. 1987; 6:167-171

14. Murashige T, Skoog F. A revised medium for rapid growth and bioassays with tobacco tissue culture. Physiologia Plantarum. 1962; 15:473-497.

15. Jean M, Cappadocia M. In vitro tuberization in Dioscorea alata $L$. 'Brazo fuerte' and 'Florido' and D. abyssinica Hoch. Plant Cell, Tissue and Organ Culture. 1991; 26:147-152.

16. Jova MC, Kosky RG, Cuellar EE. Effect of liquid media culture systems on yam plant growth (Dioscorea alata L.'Pacala Duclos'). Biotechnology, Agronomy, Society and Environment. 2011; 15:515521.

17. Borges M, Ceiro W, Meneses S, Aguilera N, Vazquez J, infante Z, Fonseca M. (2004) Regeneration and multiplication of Dioscorea alata germplasm maintained in vitro. Plant Cell, Tissue and Organ Culture. 2004; 76:87-90.

18. Forsyth C, Van SJ. An improved method of in vitro propagation of Dioscorea bulbifera. Plant Cell, Tissue and Organ Culture. 1982; 1:275-281

19. Alizadeh S, Mantell SH, Viana AM. In vitro shoot culture and microtuber induction in the steroid yam Dioscorea composita Hemsl. Plant Cell, Tissue and Organ Culture. 1998; 53:107-112.

20. Thomas P, Ravindra MB. Effects of pruning or removal of in vitro formed roots on ex vitro regeneration and growth in micropropagated grapes. Plant Cell, Tissue and Organ Culture. 1997; 51:177-180.

21. Waez VJ. The effect of activated charcoal on in vitro propagation of eastern European orchids. Acta Horticulturae. 1987; 1:131-138.

\section{How to cite this article:}

Gopal Samy B, Jegatheesan K, Francina CI. In-Vitro Propagation of Dioscorea alata for Tyrosinase Production. J App Biol Biotech. 2017; 5 (02): 085-088. DOI: 10.7324/JABB.2017.50213 